\section{NORMALIZED-DIFFERENCE SNOW INDEX (NDSI)}

Dorothy K. Hall ${ }^{1}$ and George A. Riggs ${ }^{2}$

${ }^{1}$ Crysopheric Sciences Branch, Code 614.1,

NASA/Goddard Space Flight Center, Greenbelt, MD, USA

${ }^{2} \mathrm{SSAI}$

Lanham, Maryland, USA

\section{Definition}

Normalized-Difference Snow Index (NDSI) - normalized difference of two bands (one in the visible and one in the near-infrared or short-wave infrared parts of the spectum is used to map snow. Snow is highly reflective in the visible part of the EM spectrum and highly absorptive in the near-infrared or short-wave infrared part of the spectrum, whereas the reflectance of most clouds remains high in those same parts of the spectrum, allowing good separation of most clouds and snow.

\section{Introduction}

The NDSI has a long history. The use of ratioing visible (VIS) and near-infrared (NIR) or short-wave infrared (SWIR) channels to separate snow and clouds was documented in the literature beginning in the mid-1970s by Valovin $(1976,1978)$ and also by Kyle et al. (1978). A considerable amount of work on this subject was conducted at, and published by, the Air Force Geophysics Laboratory (AFGL) (e.g., see Bunting and d'Entremont, 1982). The objective of the AFGL work was to discriminate snow cover from cloud cover using an automated algorithm to improve global cloud analyses. Later, automated methods that relied on the VIS/NIR ratio were refined substantially using satellite data, by Crane and Anderson (1984), Dozier (1989), and Rosenthal and Dozier (1996) for regional scales, and by Riggs et al.

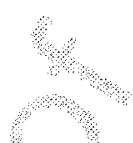

(1993), Hall et al. $(1995,2002)$, and Hall and Riggs 35 (2007) for global snow-cover mapping. In this section, 36 we provide a brief history of the use of the NDSI for map- 37 ping snow cover.

Band ratios used to discriminate snow and clouds 39 Results of an investigation of snow reflectance character- 40 istics using data from Skylab Earth Resources Experiment 41 Package (EREP) S192 multispectral scanner are presented 42 by Bames and Smallwood (1975). For the first time, satel- 43 lite study of snow from the spectral range extending from 44 the VIS to the IR $(0.41-12.5 \mu \mathrm{m})$ was possible, and this 45 paved the way for automated snow-cover mapping. 46 Shortly thereafter, Valovcin (1976) at AFGL introduced 47 the idea of using the ratio of radiance values in the VNIR 48 $(0.68-0.76 \mu \mathrm{m})$ and NIR or SWIR $(1.55-1.75 \mu \mathrm{m})$ to pro- 49 vide a method to discriminate between snow cover and 50 clouds. Kyle et al. (1978) used the ratio of the 1.6- 51 $0.754 \mu \mathrm{m}$ channels to distinguish snow and clouds using 52 a cloud physics radiometer with $0.7541 .64 \mu \mathrm{m}$ channels. 53 They also used an IR band to test for surface temperature 54 further distinguished snow and clouds.

Additional work done at AFGL by Bunting and 56 d'Entremont (1982) employed a $1.6 \mu \mathrm{m}$ sensor flown on 57 the Defense Meteorological Satellite Program (DMSP) 58 Special Sensor C (SSC) to separate snow and clouds. They 59 also used $11 \%$ reflectance to define the lower bound of 60 reflectance for snow cover. Crane and Anderson (1984) 61 reviewed the previous work, mainly conducted at AFGL, 62 and employed the DMSP Operational Linescan System 63 (OLS), which operated in the $0.4-1.0 \mu \mathrm{m}$ and $8-13 \mu \mathrm{m} 64$ range, along with $\mathrm{SSC}$ data $(1.51-1.63 \mu \mathrm{m})$. They 65 cmployed reflectances derived from the various sensors 66 to map snow using a threshold technique.

More-sophisticated use of band ratios as applied with 68 Landsat Thematic Mapper TM data was developed by 69 Dozier $(1987,1989)$. The normalized difference of TM 70 
400 tions where snow is considered to be impossible. Smal 101 specks of erroneous snow that show up on an image may 102 be due to sand. If the band $31(10.780-11.280 \mu \mathrm{m})$ tem103 perature is $>283 \mathrm{~K}$, then a pixel is considered "not snow" 104 This type of thermal test of surface temperature hadprevit05 ously been used by Kyle et al. (1978) and Romanov and 106 Gutman (2000). The standard MODIS cloud mask is also 107 employed as an input to the snow algorithm.

108 Following the 1999 launch of the MODIS on the Terra 109 spacecraft, the snow algorithm was modified several 110 times, but the NDSI has remained the basis of the algo111 rithm. The current algorithm is Version 005 (see Riggs 112 et al., 2006).

\section{Summary}

114 The term normalized-difference snow index (NDSI) was 115 coined by Hall et al. (1995), but the NDSI technique 116 already had nearly a 20 -year heritage as similar methods 117 using various visible and near-infrared bands had been 118 used since the mid-1970s to map snow and separate snow 119 from most clouds. Following the launch of the MODIS in 1201999 , the NDSI approach to mapping snow cover became 121 automated using an algorithm that utilizes the NDSI along 122 with a variety of threshold tests.

\section{Bibliography}

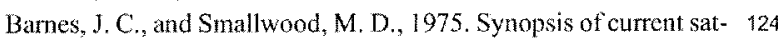
ellite snow mapping techniques with emphasis on the application 125 of near-infrared data. In Rango, A. (ed.), Operational Applica- 126 tions of Satellite Snowcover Observations. NASA Special Publi- 127 cation SP-391, pp. 199-213. 128

Bunting, J. T., and d'Entremont, R. P., 1982. Improved cloud detec- 129 tion utilizing Defense Meteorological Satellite Program near 130 infrared measurements, Air Fone Geophysics Laboratory, Lnvi- 131 ronmental Research Papers, No, 765, AFGL-TR-82.0027, 27132 January $1982,91 \mathrm{pp}$. 133

Crane, R. G., and Anderson, M. R., 1984. Satellite discrimination of 134 snow/cloud surfaces. International Journal of Remote Sensing, 135 $5(1), 213 \cdots 223$

Dozier, J., 1987. Remote sensing of snow chanacteristics in the 137 southern Sierra Nevada, "Large Scale Effects of Seasonal Snow 138 Cover," Procedings of the Vancouver Symposium, August 130 1987 . LAHS, 166 , pp. $305-314$.

Dozier, J, 1989. Spectral signature of alpine snow sover from the 141 Landsat Thetratic Mapper. Remote Sensing of Enwonment, 142 $28,9-22$. 143

Dozier, J., and Marks, D., 1987. Snow mapping and classification 144 from Landsat Thematic Mapper data. Annals of Glaciology, 9, 145 $1-7$

Hall, D. K, and Riggs, G. A., 2007. Accuracy assessment of the 147 MODIS snow-cover products. Hydrological Processes, 21, 148 $15 \% 4.647$.

Hall, D. K., Riggs, G. A., and Salomonson, V. V., 1995. Develop- 150 mentof methods for mapping global snow cover using Moderate 151 Resolution Imaging Spectroradiometer (MODIS) data. Remote 152 Sensing Environment, 54, 127-140.

Ha1l D. K., Riggs, G. A., Salomonson, V. V., DiGirolamo, N. E., 154 and Bayr, K. J., 2002. MODIS snow-cover products. Rentote 155 Sensing of Environment, 83, 181-194. 156

Klein, A. G., Hall, D. K., and Riggs, G. A., 1998. Improving snow- 157 cover mapping in forests through the use of a canopy reflectance 158 model. Hydrological Processes, 12, 1723-1744. 159

Kyle, H. L. Curran, R. J., Barnes, W. L., and Escoe, D., 1978. 160 A cloud physics radiometer, Third Conference on Atmospheric 161 Radiation, American Meteorological Society, 28-30 June 162 1978, Davis, Calif., p. 107.

Riggs, G. A. Hall, D. K., Barker, J. L., and Salomonson, V. V., 164 1993. The Developing Moderate Resolution Imaying Spectrora- 165 diometer (MODIS) Snow Cover Algorithm, Proceedings of the 166 50ih Anmual Eastern Snow Conference. 8-10 June. Quebec, 167 Canada: Quebec City, pp. 51-58.

Riggs, G. A., Hall, D. K, and Salomonson, V. V., 2006. MODIS 169 Snow Products User Gude. http//modis-snow-ice.gsfc.nasa. 170 gov/sugke2. html.

Romanov, P., and Gutman, G., 2000. Automated monitoring of 172 snow cover over North America with multispectral satellite data, 173 Journal of Applied Meteorology, 39, 1866-1880. 174

Rosenthal, $W$., and Dozier, J., 1996. Automated mapping of mon 175 tane snow cover at subpixel resolution from the Landsat The- 176 matic Mapper. Water Resoures Research, 32(1), 115-130. 177

Valovcin, F. R., 1976. Snow/cloud discrimination, AFGL-TR-76- 178 0174. ADA 032385.

Valovcin, F. R., 1978. Spectral radiance of snow and clouds in the 180 near infrared spectral region, AFGL-TR-78-0289, ADA 063761. 181 